\title{
Nature of Examination Malpractices in Grade Twelve National Examinations: Evidence from Selected Secondary Schools in Kitwe District of Zambia.
}

\author{
Gladys Maheka ${ }^{1 *}$, Beatrice Matafwali ${ }^{2}$, Benson Njovu $^{3}$, Marien Matafwali $^{4}$ \\ ${ }^{I}$ Gladys Maheka: University of Zambia, Department of Educational Psychology and Special Education \\ ${ }^{2}$ Beatrice Matafwali: University of Zambia, Department of Educational Psychology and Special Education \\ ${ }^{3}$ Benson Njovu: University of Zambia, Department of Library and Information Science \\ ${ }^{4}$ MarienMatafwali: ZCAS University, School of Social Sciences
}

*Corresponding Author: Gladys Maheka, Gladys Maheka: University of Zambia, Department of Educational Psychology and Special Education

\begin{abstract}
The study aimed establishing the nature of examination malpractice in selected secondary schools in Kitwe District. Numerous reports on both print and electronic media have consistently confirmed incidences of examination malpractices particularly in national examinations. Seven Schools drawn from the seven supervisory zones in Kitwe District participated in this study. The participants were 112 grade twelve learners (56 males and 56 females), 28 teachers (14 males and 14 females), 7 School Managers ( 3 males and 4 females) and 1 Education Standards Officer (male).A survey questionnaire was administered to grade twelve learners and teachers. Two sessions of Focus Group Discussions with grade twelves learners to share their perceptions on examination malpractices. The study confirmed high incidence of examination malpractice in the participating schools. The study further established that examination malpractice is learnt through observation .Examination malpractices mainly take the form leakages, taking foreign materials, collusion, body writing, hiding materials, and grafting.
\end{abstract}

Keywords: Examination malpractice, leakages, observation, imitation.

\section{INTRODUCTION}

The Zambian education system follows a three tier structure: Early Childhood Education-Primary; Secondary; and Tertiary Education. Transition from one tier to another is traditionally managed through national examinations that seek to assess learner competence as a criteria for selection. These examinations primarily take the form of formal testing with the goal of ascertaining the person's knowledge or proficiency in a subject or skill. Keeves (1994) has contended that nearly all countries around the world conduct examinations which are usually set at the school level, regional level and national level. Examinations have played a crucial role in managing transition at the three levels, informing selection of learners in the transition process, and certifying competence levels of the learners. It is undeniable that examinations have over the served as a quality measure in the school system. They provide indices upon which most education related decisions about the learner and their progression modalities is based. Examinations have also been used to generate data to establish a trend on how the education system is fairing. Examination can also help to ascertain the amount of knowledge, skills, attitudes that learners have acquired and the extent to which they are able to utilize them (Asuru, 2010).There is also an opportunity to gauge the behavior of learners when confronted with a series of questions, problems, tasks or situations in the learning process.

\section{LITERATURE REVIEW}

Beyond selection and certification, examinations play a crucial role in assessing learner performance and educational achieving allowing generation of comprehensive results comparableat the school level, regional level, and national level. This is an equally important dimension in measuring progress of the policy especially in the Zambia context where the education system is confronted by gaps in internal efficiency including poor learner outcomes particularly in literacy and numeracy(Linehan, 2005; Matafwali\& Bus, 2012;) and low completion levels (Education Statistical Bullentin, 2018). 
While the intention of examinations is to test the knowledge, skills, understanding, and competence of the learners, they have recently been a subject of abuse and misconceptions. To some learners, examinations have been misconstrued as a means of sifting weaker students out of the education system and keeping the stronger ones in the system. As such, a culture of survival of the fittest has promulgated the examination system inducing fear among learners and parents which unfortunately has given room to examinations malpractices.

Evidence has shown that there are different forms of examination malpractices including: impersonation, conniving with supervisors and school authorities to cheat and body writing or tattoo in which students especially females write on hidden parts of their bodies, falsification, cheating, and bribery (Jacob \&Lar, 2001).Other forms of examination malpractice includes hiding materials in washrooms, pockets, private parts, pen corks, writing answers on question papers and exchanging them with others to copy, communicating orally or through gestures, using a coding system (coding or decoding) to remember or recollect learnt material, taking in already answered script and replacing them with the answer script given to them, text messaging, taking away answer scripts or sheets from the examination room, insulting or assaulting the supervisor or invigilator, taking part in mass or organised cheating in or around the examination hall and assisting candidates by invigilators or supervisors during examinations (Achio,2005). All these are used illegally as reference materials by candidates to enable them earn good marks. David et al (2002) revealed that candidates use coded or sign language to enable them cheat during examinations. A candidate may produce a sound or drop something in order to attract the attention of a fellow candidate so that they can communicate and share the answers during examinations.

Ekpus further observed that examination malpractice is the product of a society which nurture cheating and turns cheaters into celebrities. Children are simply modeling what they observe in the society. They have observed their parents use money to get admission, a job or high position of the society, hence they do not see anything wrong with examination malpractice. This implies that whenever children witness dishonesty in the environment where they live, they vicariously learn the habit of being dishonest in their dealings. Learning takes place through observation and modeling the observed behavior. According to Albert Bandura, "Of the many cues that influence behavior, at any point in time, none is more common than the actions of others" (Bandura, 1986: 206). Individuals learn vicariously about the usefulness and appropriateness of behaviors by observing models and the consequences of modeled behaviors and they act in accordance with their beliefs concerning the expected outcomes of actions. As the models get reinforced or punished for their behavior, children or adults modeling them also make adjustments to their behavior based on those consequences (Woolfolk, 1995). All of this according to Bandura is called reciprocal determinism (Hill, 2002; Woolfolk, 2004) as cited by (Munsaka, 2011).Reciprocal is a model composed of three factors that influence behavior. The three factors are the environment, individual and the behavior. There is also evidence that all learning phenomena resulting from direct experience and modeling can occur vicariously by observing or if not by hearing of consequences for them (Bandura, 1986; Rosenthal \& Zimmerman, 1978).

Our assumption is that learners are found around individuals who may have involved themselves in examination malpractice. They have seen others be it siblings; relatives or friends make it to other levels of education through examination malpractices. The objectives of the study were threefold: i) prevalence of examination malpractices; ii) types of examination malpractices; iii) interrogate the underlying factors why learners engage in examination malpractices.

\section{MethodS}

A descriptive survey was used in this study. It included schools from all the seven supervisory zones in Kitwe District. The target population comprised grade twelve learners from seven secondary schools. From each school, about 16 learners answered the questionnaire totaling to 112 participants (56 males and 56 females). Sampling of learners included formulation of a sampling frame of each cluster based on the class registers by the school. From each school, 16 learners were recruited using systematic random sampling. Every $5^{\text {th }}$ student was selected from the sampling frame once the first student was randomly selected. It was these learners who answered the survey questionnaire at the time the school authority determined. In order to determine the sample size for this study, only one school was randomly sampled in each zone where the sampling process favored public schools because they were more in number than private schools. 
In order to have an adequate and representative sample, it was decided as a matter of research prudence that each sample unit in the population (or recruit) ought to have a chance of being selected. Because of the heterogeneous nature and the numerous factors that occasion examination malpractice, like sex and geography inter alia, systematic random sampling was used. The first stage was to develop strata along zones. There are seven zones and each has a mixed composition disproportionately of secondary schools and only one school was picked. The second stage was to develop a sampling list of all students. On this list of one school from each zone, names of pupils were tagged by a researcher to a random number. Data collection was done by the researcher.

\subsection{Conferring Validity and Reliability of the Survey Questionnaire}

A Pilot study being a small-scale version of the larger proposed study or trial runs of methods and measures was done at one of the secondary schools in Lusaka on a sample of twelfth graders. The internal consistency of the scale and data collected was tested using Cronbach's alpha which produced a co-efficient of 0.85 . The research proved that the value of this alpha is greater than 0.5 and is acceptable in social sciences (Nunally, 1978).

Questionnaires were used to collect data from grade twelve learners. Questionnaires are used to collect both qualitative and quantitative data. Quantitative data was collected using closed ended questions while qualitative data was collected using open ended questions. Questionnaires were used because they were cheap and easy to administer. Self-administered questionnaires can also be completed at the respondent's convenience without the influence of the researcher (Kombo \& Tromp, 2006).

Focus Group Discussion guides (FGD) were used to collect data from learners. Kombo and Tromp (2006) describe a focus group discussion as a special group in terms of its purpose, size, position and procedure. Focus group discussions are used to assess needs, develop interventions and test new ideas and programs. The researcher used focus group discussions because they were effective and time saving. They were ideal for grade twelve learners because they were homogeneous.

\section{Results}

This section presents findings on the nature and causes of examination malpractices. Table 1 presents the number of grade twelve learners who were engaged in examination malpractice from the seven selected Secondary Schools in Kitwe District.

Table1. Prevalence of examination malpractice

\begin{tabular}{|l|l|l|l|}
\hline \multirow{2}{*}{ Gender } & Learners involvement in examination malpractice & \multirow{2}{*}{ Total } \\
\cline { 2 - 4 } & Yes & No & \\
\hline Male & 37 & 19 & 56 \\
\hline Female & 39 & 17 & 56 \\
\hline Total & 76 & 36 & 112 \\
\hline
\end{tabular}

A survey questionnaire was administered to 112 grade twelve learners. From 112 learners, 76 learners were involved in examination malpractice, 37 were male while 39 were female. There was no significant association between gender and examination malpractice $(\mathrm{p}=0.686)$. This therefore, entails both male and the female learners are likely to engage in examination malpractices.

\subsection{Teachers' Responses on Gender and Examination Malpractice}

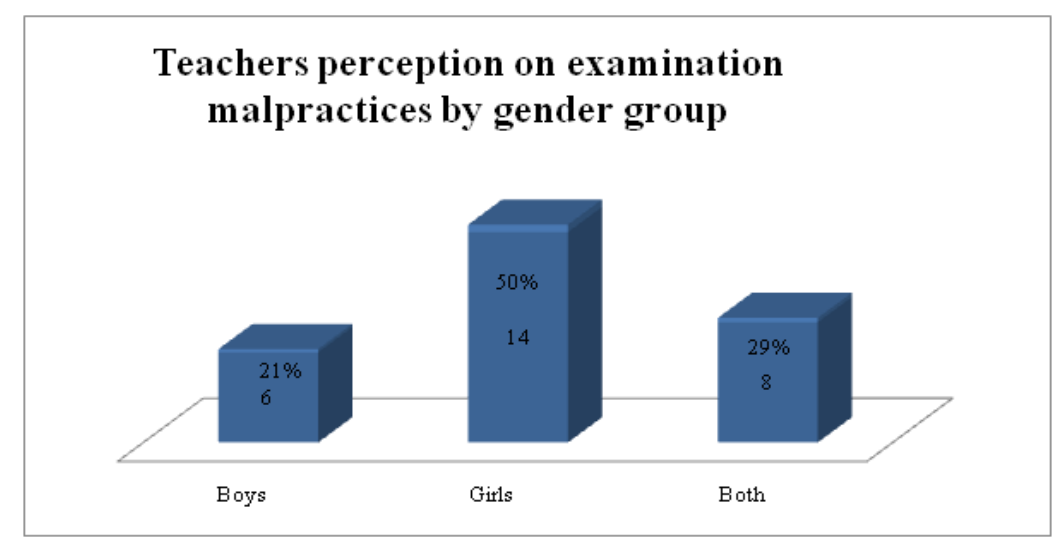


Views of teachers seem to indicate that girls are more prone to examination malpractice than boys. For instance, out of twenty eight teachers who participated in the study, 14 of the teachers indicated that there are more girls who engage themselves in examination malpractice than boys, 6 of the teachers said that there are more boys involved in examination malpractice while 8 observed that both boys and girls involve themselves in examination malpractice. Thus, from the teachers' perspective, examination malpractice is common among girls compared to boys.

\subsection{Examination Malpractices by Type of School.}

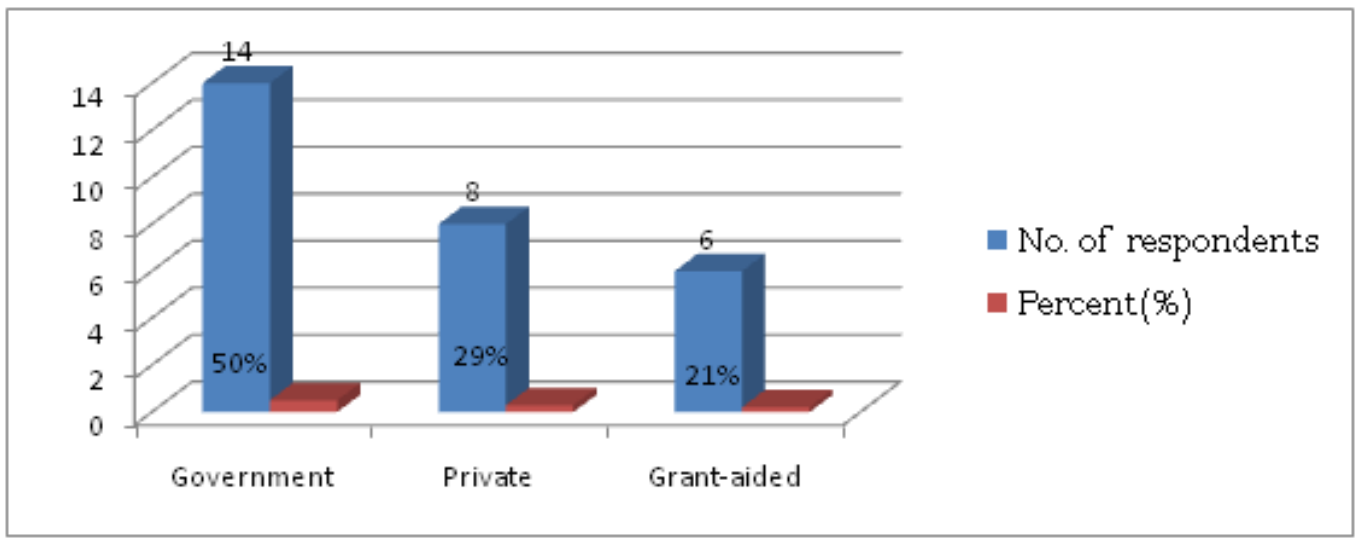

Concerning the types of schools and examination malpractice, 14 of the teachers indicated that examination malpractice was more in government schools, 8 said that examination malpractice was more in private schools while 6 of the teachers noted that examination malpractice was more in grantaided schools. Therefore, from the teachers' perspective examination malpractice is more in government schools than in private and grant- aided schools.

\subsection{Nature of Examination Malpractices}

On the nature of examination malpractices, the findings as presented in the figure below seem to indicate that leakages, taking foreign materials, collusion, body writing, hiding materials, and grafting are the most common forms of examination malpractices.

\section{Nature of Examination Malpractices}

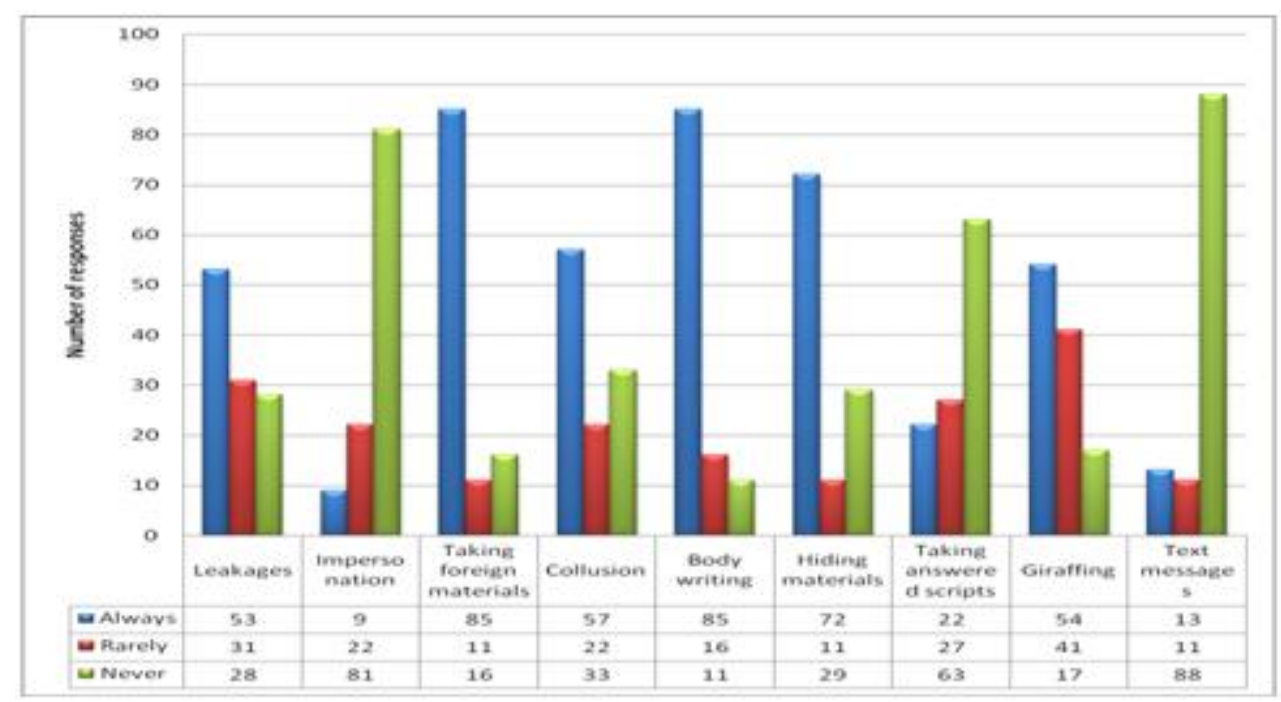

During the focus group discussion, school administrators and learners were asked to elaborate on the nature of examination malpractices.

A male grade twelve learner had this to say regarding leakages;

Leakage is always there (genuine ones) and we use them because everyone else uses them and nothing happens whether they are caught or not. So why should we be studying when leakages are there and we have seen people use them, go to Colleges again use them until they finish school. They are the ones who even have good jobs. 
During interviews with school managers, it was revealed that leakage was common during examinations. Candidates had prior knowledge of examination questions before the actual examination day.

A male School Manager from one of the secondary schools in Kitwe stated that;

Last year most of the learners at this school had access to the leaked material and during examinations they got into the examination room with the original paper which they were writing. Some had answers I mean exact answers the way they appeared on the marking key written on small pieces of paper and sneaked into the examination room

Overall, the study has revealed that examination malpractices are prevalent in all schools; public, private and grant-aided. Among the common forms are leakages, taking foreign materials, collusion, body writing, hiding materials, and grafting.

\section{DISCUSSION}

The study revealed that learners in the seven selected Secondary Schools hide materials in washrooms, pockets, private parts, pen corks, write answers on question papers and exchanging them with others to copy, communicate orally or through gestures, using a coding system (coding or decoding) to remember or recollect learnt material and assisting candidates by invigilators or supervisors during examinations. Candidates may use coded or sign language to enable them cheat during examinations by producing a sound or dropping something in order to attract the attention of a fellow candidate so that they can communicate and share the answers during examinations. These forms of examination malpractice are an indication that both the candidates and the invigilators practice what they have observed or heard other people do during examinations. It was also surprising that candidates were able to replace an already answered script with the one given to them. This was made possible by candidates making arrangements with invigilators and supervisors before the commencement of examinations.

The study further established that candidates also engaged in examination malpractice by using materials or information that is forbidden. This was done by candidates writing information on sheets of paper, hems, calculators, writing on a wide piece of tape and putting them under the shoes, on the inside of jackets, on a water or beverage container, eyeglass cases, facial tissues, eraser, wrist watch, on or in mechanical pencils or pens along with writing on one's arms and other written aids under the table.

The motivation behind the persistent occurrence of examination malpractice is the value that society places on paper qualification. There is a significant relationship between societal values for paper qualification and students involvement in examination malpractice. Societal value on paper qualification is a determinant for students' tendency to cheat. Our society nurtures cheaters by turning them into celebrities and this has given birth to examination malpractice. Learners do what they see and not what they are told so when they observe people engage in examination malpractice they model what they observe.

The student using or not using a pre- prepared material in examination, leaving the examination hall with used answer booklets, exchanging answer materials as well as physically assaulting invigilators are common offences in this college that are not punished as severely as the handbook prescribes. This is likely to be the major reason why this act is perpetuated. Students who are found guilty are not so seriously punished to serve as deterrent to others. Many invigilators manage and cover up these offences giving the students reasons to continue (AsoRock, 2007).

InZambia on examination malpractice found that candidates were able to enter exam room with written materials or script that are already answered with the one given to them. This was made possible by candidates making arrangements with invigilators and supervisors before the commencement of examinations. Candidates colluding pre-plan to sit in such a way that will coordinate copying (Akaranga, 2011). This is done by candidates dropping a paper or answer sheet on the floor, switching papers or answer sheets or flipping or holding the answer sheet up so that the candidates behind them can copy. It is also done by candidates communicating with sign language or a code for transmitting answers such clicking of pencil, foot tapping coughing and body gestures (McCabe and Trevino, 1997). Candidates also engage in examination malpractice by using materials or information that is forbidden. This is done by candidates writing information on sheets of paper, 
hems, calculators, writing on a wide piece of tape and putting them under the shoes, on the inside of jackets, on a water or beverage container, eyeglass cases, facial tissues, eraser, wrist watch, on or in mechanical pencils or pens along with writing on one's arms and other written aids under the table (Vowell and Chen, 2004). Candidates who have access to devices such as phones, computers, printers and internet are likely to indulge in examination malpractice. The incidences of fore- knowledge of examination question papers and leakage spread fast through the use of mobile phones and internet facilities by candidates (Unachukwu\&Onunkwo, 1999). This is because the above mentioned devices can be used for high- jacking questions and marking keys especially those hooked to the internet. Candidates in the rural parts are also likely to be victims of examination malpractice.

These corrupt tendencies which have characterized the education system if not well managed will make it difficult to base judgement of a learner's performance on examinations and the education system will run the risk of rendering the purpose examinations almost inconsequential. Some scholars have attributed examination malpractices to societal attitude that has placed a lot of value on paper qualification and this unintentionally has encouraged examination malpractices as means of survival in a competitive society. The findings in a study conducted by Ekpus (1991) indicated a significant relationship between societal values for paper qualification and students involvement in examination malpractice. Societal value on paper qualification is a determinant for students' tendency to cheat (Onyibe, Uma \&Ibina, 2015).

In Nigeria, Petters and Okon (2014) found that societal preference for paper qualification, lack of positive self-concept, lack of effective study skills, inadequate preparation and laziness as major causes. While Onyibe and Uma (2015) found that perennial lack of political will on the part of government to enforce examination decrees and examination Malpractice Acts as weaknesses that make examination misconduct to remain on the increase in Nigeria. Adeyemi (2010) found similar causes, that is, indiscipline among students, non-implementation of the examination malpractices decree and the lack of effective supervision of students during examinations. Udoh (2011) also realized poor study habits, paucity of educational facilities and inability of schools to cover prescribed syllabuses as significant remote causes of examination malpractice in the same country, Nigeria.

Teachers have also been implicated as perpetrators of examination malpractices. Some teachers who are assigned to supervise examination connive with students to cheat due to the level of poverty. Confirming the above view, Ezezogor (1982) said that students' involvement in examination malpractice is due to teachers' encouragement. According to the author, teachers and principals aid students in buying questions papers of the examination to be written. For instance, in some secondary schools, there is what is popularly known as cooperation fee which is paid by every student who registered for such examination. This is to enable teachers, principals and supervisors to help them throughout the period of examination. Okoro (2001) is of the view that the patterns of the examination questions set by the teachers sometimes encourage some students' to engage in malpractice. This implies that questions that require reproduction of facts by students will make them to find the facts somewhere when they cannot draw immediately from their memory.

Newberger (2003) claimed that the disinclination of the teacher to pursue evidences of cheating is based on sympathy, for students are trying to cope in a grade-oriented system. The author further posited that the overwhelming testimony of high school students is that when a student is caught cheating, the teacher out of sympathy, misguided or not, or out of desire to avoid personal confrontation with the student or the parents, often looks the other way. This is true even in Nigerian school system where teachers often do not report cases of cheating for fear that the students may think, they are wicked. Teachers therefore sympathize with students by hiding incidence of cheating during examination. Confirming this fact further Newberger (2003) said that a high school teacher teaching a class drawn from a low-achieving track, deliberately leaves the room for a few minutes during each test so that the students can swap answers. This action is rationalized on the bases that those students need 'all the help they can get'.

Yusuf, Olofunke and Bamgbose (2015) investigated undergraduates' perceptions of factors responsible for examination malpractice in Osun State University in Nigeria. Their findings revealed poor study habits, poor concentration during lectures, and peer influence. The descriptive study had a sample population of 200 undergraduates. Data collected were analyzed using frequency counts, mean scores, t-test and ANOVAs. The study recommended that functioning counseling units should be 
established in tertiary institutions to provide guidance to students on educational issues and other related problems. The study also recommended that the school management should enforce strong punitive measures to any students that engage in examination malpractice.

Examination malpractice has many negative impacts. According to Akaranga and Ongong (2013), examination malpractice often leads to expulsion of students from academic institutions. While Adelakum and Lawal (2008), the effects of examination malpractice are erosion of confidence in the education system and loss of credibility in the education assessment, loss of confidence in examination agencies, which leads to loss of confidence in the certificates that are issued by the agencies and rising cost of conducting examinations, especially in areas where leakage has been documented.

Alutu and Alutu (2003) personal factors are those deemed to be perpetuated by individual. The following causes fell under this category: unpreparedness by the students, habit to cheat, poor study habits, lack of confidence by the students and laziness by students. Both the teachers and the students reported that many students are not prepared for examinations due to laziness as well as to not taking their studies seriously. The respondents reported that many students spend their time in doing activities that do not profit their education such as playing casual soccer or watching movies instead of concentrating on their studies. It was further reported that even though students may prepare very well for the examinations, they are sometimes engulfed by fear of failure and forgetfulness. Therefore, to remind themselves of what they have read, they sometimes engage in cheating by going into the examination halls with unauthorized materials.

Research by Adeyemi (2010) found that Secondary school students' perceptions of examination malpractices and examination ethics were assessed. The participants were drawn from Secondary Schools in the Benin Metropolis of Nigeria. The study revealed that majority of the students believed that their indulgence in examination malpractice was a common occurrence, which will be difficult to eradicate. Azukaet al (2006) found that Parents, teachers and school principals were found to encourage cheating in examinations. The study also revealed that majority of the students had a very wrong notion about examination ethics; believing that examination ethics entail among others sitting next to someone in order to copy from his/her paper in the examination hall. In all, counselling intervention strategies such as, school counsellors partnering with the school authorities and students to set up examination ethics clubs that will teach the virtues of hardwork; school counsellors partnering with parents/teachers association and other significant others on strategies that would help to inculcate in them the virtues of "responsibility" were advocated.

As a result, education implementers are not able to administer examinations without malpractices because of insufficient remuneration, corruptive behaviour of lecturers, teachers' pressure from students, relationship influence and compromised supervision. Similarly, Jimoh (2009) reported that students' non-challant attitude, parental indiscipline, supervisors and invigilators' gratification and compulsive demands, poor teachers' motivation and emphasis on certification bring about examination fraud.

\section{CONCLUSION AND RECOMMENDATION}

These outcomes confirm prevalence of examination malpractice. Learners engage in examination malpractice because they have seen society engage in examination malpractice and excel through without being punished. The curriculum which is based on cognitive skills and the limited places at tertiary education are all recipes for examination malpractice. The forms of examination malpractice involve collusion, cheating and leakage among others. We therefore, recommend a stiffer punishment to the would be culprits so to deter other learners from engaging into the vice. We further recommend that our curriculum should emphasisepracticalsubjects such as woodwork, metal work, home economics and art and design which do not invoke rote learning.

\section{REFERENCES}

[1] Achio, S. (2005).Academic malpractices analysis of disciplinary measures taken against student culprits on the HND Program in Accra Polytechnic from 2000- 20003 JOPOG. Vol. 1, No.1, November, 2005, PP. 31- 41.1, Nov. 2005, PP. 31-41.

[2] Adeyemi, T. O. (2010). Examination malpractices among secondary school students in Ondo State, Nigeria: Perceived causes and possible solutions. Journal of Education Administration and Policy Studies. 2(3). http://www.academicjournals.org/JEAPS 
Nature of Examination Malpractices in Grade Twelve National Examinations: Evidence from Selected Secondary Schools in Kitwe District of Zambia.

[3] Akaranga, S.I. (2011). The Phenomenon of Examination Malpractice: An example of Nairobi and

[4] Alutu, O.E. and Alutu, A.N.G. (2003). Examination malpractice among undergraduates in a Nigerian University: Implications for Academic advising. Guidance and Counselling, 18: 149-152

[5] Asuru, V.A. (2010).Beyond Cognitive Assessment: Mechanisms for Reducing System Generated Causes of Examination Malpractice. Journal of the Association for Educational Assessment in Africa. Volume 4, pp 105-113.

[6] Azuka N. G. Alutu, Oyaziwo Aluede (2006). Secondary Schools Student's Perception of Examination Malpractices and Examination Ethics.

[7] Bandura, A. (1986). Social foundations of thought and action: A social cognitive theory. Englewood Cliffs, NJ: Prentice-Hall.

[8] David etal, (2002) The Complete Idiots Guide to Understanding Ethics, London: Penguin.

[9] Ekpus, R. (1991). Examination cheats. News week, July 1, pp 570.

[10] Ezezogor, S.A. (1982). West African Examination leakages. Journal of all Nigerian conference of principals of secondary schools. 21, 130-137 http://www.sciencedirect.com/science/article/pii/ S1877042 81305310X.

[11] International Journal of Administration, Planning \& Research 1(1) 105 - 114.

[12] Jacob, S. \&Lar, T.D. (2001). Forms and reasons for Examination malpractice: Implication for National Development. Proceeding of the 16th Annual congress of the Nigerian Academy of Education. Pp 355365. Jos: The Nigerian Academy of Education.

[13] Kombo, J. and Tromp, S. (2006). Applied Research Methods. Nairobi: Paulines.

[14] Linehan, S. (2005). Language of instruction and the quality of basic education in Zambia. Paper commissioned for the EFA Global Monitoring Report.

[15] Matafwali, B. \& Bus, A.G. (2013). Lack of familiarity with the language of instruction: A main cause of reading failure by grades 1 and 2 pupils in Zambia. Insights on Learning Disabilities, 10, 31-44.

[16] McCabe, D.L. \& Trevino, L.K. (1997).Individual and Contextual Influences on Academic Dishonesty: a multicampus investigation, Research in Higher Education, 38 (3), pp. 379-396.

[17] Munsaka, E. (2011).Mastering the Psychology of Teaching and Learning, Lusaka: Zambia Mission Press.

[18] Newberger, E. H. (2003). "The men they will become: The nature and nurture of the male character" retrieved on 5/9/2005 from www.schoolforchaimpoins.com/characterNewbergercheating3.html.

[19] Nunally, J.C. (1978), Psychometric Theory. McGraw-Hill, New York, NY.

[20] Okoro, E.C. (2001). The impact of examination malpractice on the functionality of education in Nigeria.

[21] Onyibe, C. O. \& Uma. E. (2015). Examination malpractice in Nigeria: Causes and effects on national development. Journal of Education and Practice. www.iiste.org

[22] Petters, J.S.; Okon, M,O.; (2014). Students' perception of causes and effects of examination malpractice in the Nigerian educational system: The way forward for quality education.

[23] Private Limited.

[24] Rosenthal, T.L and Zimmerman, B.J. (1978). Social Learning and Cognition pp 338

[25] Udoh, N.A. (2011). Remote causes and counseling implications of examination malpractice in Nigeria. Inquiries Journal, Social Sciences, Arts and Humanities. http://www.inquiriesjournal.com

[26] Vowell, P. and Chen, J. (2004). Predicting Academic Misconduct: A Comparative Test of four Sociological Explanations, Sociological Inquiry 74: 226-249.

[27] Woolfolk, A. (1995). Educational Psychology (6 ${ }^{\text {th }}$ ed.). Boston: Allyn\& Bacon.

Citation: Gladys Maheka, et.al. "Nature of Examination Malpractices in Grade Twelve National Examinations: Evidence from Selected Secondary Schools in Kitwe District of Zambia." International Journal of Humanities Social Sciences and Education (IJHSSE), vol 7, no. 4, 2020, pp. 163-170. doi: http://dx.doi.org/10.20431/2349-0381.0704016.

Copyright: (C) 2020 Authors. This is an open-access article distributed under the terms of the Creative Commons Attribution License, which permits unrestricted use, distribution, and reproduction in any medium, provided the original author and source are credited. 